\title{
Nutrient and Stoichiometric Characteristics of Underground Fissures Soil in Karst Rocky Desertification Regions
}

\section{Longpei Cen}

Guizhou University

Quanhou Dai ( $\nabla$ gzudjj@163.com )

Guizhou University https://orcid.org/0000-0001-9373-5097

\section{Youjin Yan}

Guizhou University

Gang Hu

Guizhou University

Quan Jiao

Guizhou University

Xingsong Yi

Guizhou University

\section{Research Article}

Keywords: underground fissures, soil nutrients, soil stoichiometry, karst rocky desertification regions

Posted Date: February 10th, 2021

DOI: https://doi.org/10.21203/rs.3.rs-176828/v1

License: (1) This work is licensed under a Creative Commons Attribution 4.0 International License. Read Full License 


\section{Abstract}

Aims Underground fissure soil is an important soil resource in karst rocky desertification area, but there are few reports on its physical and chemical properties and soil ecological stoichiometry. This study aims at investigating the physicochemical properties, nutrient content and stoichiometric characteristics of subsurface fissured soils in karst areas, which will help to understand their intrinsic linkage mechanisms and provide a scientific basis for making full use of fissured soils.

Methods Typical karst fissures were selected through a combination of field investigation and inlaboratory analysis, and soil physicochemical properties were determined through field sampling and indoor tests.

Results We found that as the depth of the fissure soil layer increases, the silt content and clay content increase and the sand content and soil water content continue to decrease. The fissure soil is basically weakly alkaline. The TN content does not change much from the surface to the lower part of the fissure, and the AN, TP and AP contents in the fissure generally decrease. In general, SOC, nitrogen and phosphorus are mainly concentrated in the surface soil compared to the other soil layers in the fissure; the $\mathrm{C} / \mathrm{N}, \mathrm{N} / \mathrm{P}$ and $\mathrm{C} / \mathrm{P}$ ratios are higher in the upper part of the fissure; $\mathrm{C} / \mathrm{P}$ and N/P are higher and $\mathrm{C} / \mathrm{N}$ is lower in $\mathrm{SL}$, while the opposite is true in $\mathrm{AL}$.

Conclusions The low nutrient content and high ecological stoichiometry of karst rift soils suggest that rift soils in karst areas need more soil nutrient management, and improvement of quality status.

\section{Introduction}

It is reported that karst landforms account for $12 \%$ of the total global land area, with an area of about 22 million square kilometres (Ford and Williams et al.,2013). However, in the fragile karst geological and ecological environment, karst rocky desertification caused by soil erosion and unreasonable and intensive land use has become a serious environmental and social problem in the world (Wang et al., 2004).

The southwestern China karst area centred on Guizhou Province is the world's largest continuous karst area (Li et al., 2017b; Peng et al., 2017)

.and the special ecological geological characteristics make this area a typical fragile ecological environment(Wang et al.,2004b). With the intensification of stone desertification, soil erosion in karst areas is becoming increasingly serious((Febles-González et al., 2014), and the ability to support plant growth is severely weakened, leading to vegetation degradation, which in turn leads to the destruction of the basic structure of karst soils, soil infertile, water-holding capacity reduced, and plants subjected to frequent deteriorating environmental stress, leading to the inability of vegetation to grow normally or eventually to die, increasing the risk of karst stone desertification and further leading to the collapse of karst ecosystems, all of which directly or indirectly cause serious challenges to the productivity and sustainability of karst soil resources (Smith et al., 2013) 
.And the special surface-subsurface dichotomy of the Tongkat region leads to soil erosion in two directions. During the runoff-driven downward loss of soil through the fissure system, part of the soil is temporarily stored in the shallow karst fissures, forming the fissure soil system. Studies have shown that the fissure soil system has become one of the important plant habitats in karstic stone desert slopes, which can provide water, nutrients and the spatial basis for plant growth, and is a good place to promote vegetation restoration projects (Waltham et al.,2008; Xiong et al.,2018). Soil organic carbon (SOC), nitrogen $(N)$ and phosphorus $(P)$ are important indicators of soil fertility and quality(Lal et al.,2004; Andrews and Karlen et al.,2004). Soil organic carbon has an important role and significance in influencing soil physical and chemical properties, regulating soil structure, reflecting land productivity and environmental health functions, and nitrogen significantly increases primary productivity in most terrestrial ecosystems (Hua et al.,2015), Phosphorus levels can directly affect plant growth and development (Ruttenberg et al.,2003), In summary, the cycling of carbon, nitrogen and phosphorus in soils is closely related (Vitousek et al.,2004) and is an essential nutrient for the restoration and growth of karst vegetation. The soil conditions of the shallow karst subsurface fissures are different from those of the surface, and therefore the physical and chemical properties and nutrients of the soil are also different from those of the surface, so the study of fissured soils in this area can be of great scientific importance for the implementation of revegetation and improvement of soil quality.

At present, many scholars have mainly focused on the physicochemical properties of soils under different rock-desertification classes (Ma et al., 2020) or the nutrient and stoichiometric characteristics of soils, the topsoil under different land use practices (Han et al., 2015; Wang et al., 2018b; Wang et al., 2020), or the nutrient characteristics of different karst topographies (peaks, depressions, etc.) ( Liu et al., 2014; Yang et al., 2019; Zhang et al., 2013), the influence of karst lithology on nutrients (Wang et al., 2018b), while some researchers have focused on the nutrient dynamics of degraded agricultural soils (Li et al., 2017a; Wen et al., 2016). However, most studies have focused on the physicochemical properties of surface soils, such as organic carbon and nitrogen cycling, and less research has been conducted on the physicochemical properties, nutrient and ecological stoichiometric characteristics of karst fissure soils. Therefore, this study aims to investigate the physicochemical properties, nutrient content and stoichiometric characteristics of subsurface fissure soils in karst areas, which will help to understand their intrinsic linkage mechanisms and provide a scientific basis for making full use of fissure soils. The results of the study can provide a certain basis for the restoration of vegetation and the rational use of soil resources in karst stone desertification areas, and have certain guiding significance for the ecological restoration and management of karst stone desertification areas.

\section{Materials And Methods}

Study area and sites

The study was conducted from July 2017 to August 2017 in the Xinfa Small Watershed, located in Zhenning County, Anshun City, Guizhou Province, China, at latitude $26^{\circ} 06^{\prime}-26^{\circ} 07^{\prime}$ North and longitude $105^{\circ} 49^{\prime}-105^{\circ} 50^{\prime}$ East, in a typical karst region of Guizhou Province, China (Fig. 1). The region has a humid 
subtropical monsoon climate, with an average temperature of $14.03^{\circ} \mathrm{C}$ and an accumulated temperature $\left(\geq 10^{\circ} \mathrm{C}\right)$ of $4116^{\circ} \mathrm{C}$, annual average rainfall of about $1193 \mathrm{~mm}, 960-1300$ hours of sunshine, an average frost-free period of 294 days and annual average land evaporation of $550 \mathrm{~mm}$. The soil type is predominantly limestone, derived from Triassic limestone. Broad-leaved subtropical evergreen forests are the dominant zonal vegetation type.

Soil sampling

In this study, A $50 \mathrm{~m} \times 50 \mathrm{~m}$ grid is laid over the study area and $6010 \mathrm{~m} \times 10 \mathrm{~m}$ sample points are set up at the grid points, within each sample point three typical fissures are selected and sample points, fissure information and soil samples are collected. The soil samples are homogeneously mixed at four levels, $0-$ $20 \mathrm{~cm}, 20-40 \mathrm{~cm}, 40-60 \mathrm{~cm}, 60-80 \mathrm{~cm}$, at the same level and labelled U1, U2, U3, U4, in that order.

Finally, the survey selected 60 typical underground shallow-layer fissures in four vegetation types:

grassland, fallow land, shrubland and tree woodland: 9, 8, 29 and 14 fissures (Table 1). 
Table 1

The basic information of fissures selected

\begin{tabular}{|c|c|c|c|c|}
\hline $\begin{array}{l}\text { Vegetation } \\
\text { type }\end{array}$ & $\begin{array}{l}\text { Abandoned } \\
\text { land }\end{array}$ & Grassland & Shrub land & Arboreal land \\
\hline & $26^{\circ} 07^{\prime} 03^{\prime \prime} \mathrm{N}$ & $26^{\circ} 06^{\prime} 30^{\prime \prime} \mathrm{N}$ & $26^{\circ} 07^{\prime} 30^{\prime \prime} \mathrm{N}$ & $26^{\circ} 07^{\prime} 15^{\prime \prime} \mathrm{N}$ \\
\hline \multirow{2}{*}{$\begin{array}{l}\text { Geographic } \\
\text { coordinate }\end{array}$} & $105^{\circ} 49^{\prime} 49^{\prime \prime} \mathrm{E}$ & $105^{\circ} 49^{\prime} 30 " \mathrm{E}$ & $105^{\circ} 49^{\prime} 30^{\prime \prime} \mathrm{E}$ & $105^{\circ} 49^{\prime} 30^{\prime \prime} \mathrm{E}$ \\
\hline & $1297-1317$ & $1284-1330$ & $1290-1397$ & $1296-1334$ \\
\hline \multicolumn{5}{|l|}{ Altitude/m } \\
\hline & $10-18$ & $5-50$ & $10-60$ & $20-30$ \\
\hline \multicolumn{5}{|l|}{ Slope ${ }^{\circ}$} \\
\hline & $50-95$ & $30-96$ & $10-95$ & $25-80$ \\
\hline \multicolumn{5}{|l|}{$\begin{array}{l}\text { Vegetation } \\
\text { coverage/\% }\end{array}$} \\
\hline & $5-50$ & $4-70$ & $5-90$ & $20-75$ \\
\hline \multicolumn{5}{|l|}{$\begin{array}{l}\text { Exposure } \\
\text { rate of } \\
\text { bedrock/\% }\end{array}$} \\
\hline & $\begin{array}{l}\text { Limestone } \\
\text { soil }\end{array}$ & Limestone soil & Limestone soil & Limestone soil \\
\hline \multicolumn{5}{|l|}{ Soil type } \\
\hline & Dolomite & Dolomite & Dolomite & Dolomite \\
\hline \multicolumn{5}{|l|}{$\begin{array}{l}\text { Bedrock } \\
\text { type }\end{array}$} \\
\hline Vegetation & $\begin{array}{l}\text { (Bidens } \\
\text { pilosa L.) } \\
\text { (Setaria } \\
\text { viridis) }\end{array}$ & $\begin{array}{l}\text { (Imperata } \\
\text { cylindrica) } \\
\text { (Cynodon } \\
\text { dactylon) }\end{array}$ & 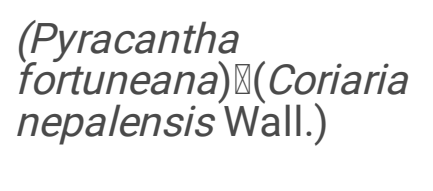 & $\begin{array}{l}\text { (Toona sinensis } \\
\text { (A.Juss.) Roem). } \\
\text { (Broussoneia papyrifera) }\end{array}$ \\
\hline
\end{tabular}

Measurement of soil physical properties and nutrients

The natural soil water content (SWC) was determined via the drying method, the soil pH was measured by extracting the liquid from a soil and water mixture (ratio of 1:5) (Institute of Soil Science of Chinese Academy of Sciences, 1978), and the soil particle distribution was determined by the pipette method. The soil organic carbon (SOC) contents were determined by oxidation with potassium dichromate under external heating, total nitrogen (TN) was measured by the Kjeldahl method, and the alkali hydrolysable nitrogen (AN) was determined by the Conway method, and the total phosphorus (TP) was measured with the Mo-Sb colourimetric method, and available phosphorus (AP) was extracted with $0.5 \mathrm{~mol} / \mathrm{L} \mathrm{NaHCO} 3$ $(\mathrm{pH}=8.5)$ and then determined by colourimetric analysis. 


\section{Results}

Physical and chemical properties of soil in fissures

The physical and chemical properties of karst fissured soil with different vegetation types in the same soil type (limestone soil) and rock type (limestone) are shown in Table 2. 
Table 2

Soil physical and chemical properties in karst fissures with different vegetation types.

\begin{tabular}{|c|c|c|c|c|c|c|}
\hline $\begin{array}{l}\text { Vegetation } \\
\text { types }\end{array}$ & $\begin{array}{l}\text { Soil } \\
\text { layers }\end{array}$ & $\begin{array}{l}\text { Soil } \\
\mathrm{pH}\end{array}$ & SWC/\% & $\begin{array}{l}\text { Sand content } \\
2-0.02 \mathrm{~mm} / \%\end{array}$ & $\begin{array}{l}\text { Silt content } 0.02 \\
\mathrm{~mm}-0.002 \mathrm{~mm} / \%\end{array}$ & $\begin{array}{l}\text { Clay content }< \\
0.002 \mathrm{~mm} / \%\end{array}$ \\
\hline \multirow[t]{4}{*}{ GL } & U1 & $\begin{array}{l}7.85 \pm \\
0.12 \\
\mathrm{Aa}\end{array}$ & $\begin{array}{l}41.43 \pm \\
12.2 \mathrm{Aa}\end{array}$ & $\begin{array}{l}44.35 \pm 12.54 \\
\mathrm{Aa}\end{array}$ & $28.65 \pm 6.29 \mathrm{Ab}$ & $\begin{array}{l}27.00 \pm 6.26 \\
\mathrm{Aa}\end{array}$ \\
\hline & U2 & $\begin{array}{l}7.82 \pm \\
0.08 \\
\mathrm{Aa}\end{array}$ & $\begin{array}{l}40.80 \pm \\
12.71 \\
\mathrm{Aa}\end{array}$ & $\begin{array}{l}37.33 \pm 10.96 \\
\mathrm{Aa}\end{array}$ & $32.33 \pm 5.52 \mathrm{Aab}$ & $\begin{array}{l}30.33 \pm 5.45 \\
\mathrm{Aa}\end{array}$ \\
\hline & U3 & $\begin{array}{l}7.91 \pm \\
0.18 \\
\mathrm{Ba}\end{array}$ & $\begin{array}{l}39.93 \pm \\
5.07 \mathrm{Aa}\end{array}$ & $\begin{array}{l}30.88 \pm 6.15 \\
\mathrm{ABa}\end{array}$ & $35.5 \pm 2.80 \mathrm{ABab}$ & $\begin{array}{l}33.63 \pm 3.37 \\
\mathrm{ABa}\end{array}$ \\
\hline & U4 & $\begin{array}{l}7.85 \pm \\
0.19 \\
\mathrm{Aa}\end{array}$ & $\begin{array}{l}32.22 \pm \\
4.36 \mathrm{Ba}\end{array}$ & $\begin{array}{l}36.38 \pm 16.44 \\
\mathrm{Aa}\end{array}$ & $33.00 \pm 8.19 \mathrm{Aa}$ & $\begin{array}{l}30.63 \pm 8.28 \\
\mathrm{Aa}\end{array}$ \\
\hline \multirow[t]{4}{*}{ SL } & U1 & $\begin{array}{l}7.78 \pm \\
0.16 \\
\mathrm{Aa}\end{array}$ & $\begin{array}{l}42.70 \pm \\
16.06 \\
\mathrm{Aa}\end{array}$ & $\begin{array}{l}48.24 \pm 14.41 \\
\mathrm{Aa}\end{array}$ & $26.72 \pm 7.36 \mathrm{Aa}$ & $\begin{array}{l}25.03 \pm 7.06 \\
\mathrm{Aa}\end{array}$ \\
\hline & U2 & $\begin{array}{l}7.76 \pm \\
0.22 \\
\mathrm{Aa}\end{array}$ & $\begin{array}{l}41.29 \pm \\
8.78 \mathrm{Aa}\end{array}$ & $\begin{array}{l}43.39 \pm 14.36 \\
\mathrm{Aa}\end{array}$ & $29.18 \pm 7.15 \mathrm{Aa}$ & $\begin{array}{l}27.43 \pm 7.22 \\
\mathrm{Aa}\end{array}$ \\
\hline & U3 & $\begin{array}{l}7.83 \pm \\
0.10 \\
\mathrm{Aa}\end{array}$ & $\begin{array}{l}34.79 \pm \\
4.85 \mathrm{Aa}\end{array}$ & $\begin{array}{l}40.79 \pm 13.30 \\
\mathrm{Aa}\end{array}$ & $30.41 \pm 6.61 \mathrm{Ba}$ & $\begin{array}{l}28.79 \pm 6.70 \\
\mathrm{Ba}\end{array}$ \\
\hline & U4 & $\begin{array}{l}7.85 \pm \\
0.16 \\
\mathrm{Aa}\end{array}$ & $\begin{array}{l}35.89 \pm \\
7.91 \\
\mathrm{ABa}\end{array}$ & $\begin{array}{l}40.83 \pm 16.61 \\
\mathrm{Aa}\end{array}$ & $30.33 \pm 8.18 \mathrm{Aa}$ & $\begin{array}{l}28.83 \pm 8.43 \\
\mathrm{Aa}\end{array}$ \\
\hline \multirow[t]{4}{*}{ AL } & U1 & $\begin{array}{l}7.81 \pm \\
0.07 \\
A b\end{array}$ & $\begin{array}{l}43.55 \pm \\
7.01 \mathrm{Aa}\end{array}$ & $\begin{array}{l}37.00 \pm 9.50 \\
\mathrm{Aa}\end{array}$ & $32.50 \pm 5.00 \mathrm{Ab}$ & $\begin{array}{l}30.50 \pm 4.53 \\
\mathrm{Aa}\end{array}$ \\
\hline & U2 & $\begin{array}{l}7.80 \pm \\
0.04 \\
\mathrm{Aa}\end{array}$ & $\begin{array}{l}41.39 \pm \\
2.26 \mathrm{Aa}\end{array}$ & $\begin{array}{l}30.75 \pm 6.71 \\
\mathrm{Aa}\end{array}$ & $35.75 \pm 3.40 \mathrm{Aab}$ & $\begin{array}{l}33.50 \pm 3.34 \\
\mathrm{Aa}\end{array}$ \\
\hline & U3 & $\begin{array}{l}7.60 \pm \\
0.06 \\
\mathrm{Aa}\end{array}$ & $\begin{array}{l}40.12 \pm \\
4.14 \mathrm{Aa}\end{array}$ & $27.6 \pm 4.20 \mathrm{Ba}$ & $37.00 \pm 2.15 \mathrm{Aab}$ & $\begin{array}{l}35.40 \pm 2.10 \\
\mathrm{Aa}\end{array}$ \\
\hline & U4 & $\begin{array}{l}7.82 \pm \\
0.12 \\
\mathrm{Aa}\end{array}$ & $\begin{array}{l}40.46 \pm \\
3.12 \mathrm{Aa}\end{array}$ & $\begin{array}{l}27.88 \pm 4.59 \\
\mathrm{Aa}\end{array}$ & $37.75 \pm 1.85 \mathrm{Aa}$ & $\begin{array}{l}34.38 \pm 3.45 \\
\text { Aa }\end{array}$ \\
\hline
\end{tabular}

Note: GL, grassland; SL, shrubland; AL, Abandoned land; FL, forestland; U1, soil (thickness of $0 \sim 20$ $\mathrm{cm}$ ) in the karst fissures; $\mathrm{U} 2$, the soil at a depth of $40 \mathrm{~cm}$ in the karst fissures; $\mathrm{U} 3$, the soil at a depth of $60 \mathrm{~cm}$ in the karst near-surface fissures; and U4, the soil at a depth of $80 \mathrm{~cm}$ in the karst fissures. The same below. 


\begin{tabular}{|c|c|c|c|c|c|c|}
\hline $\begin{array}{l}\text { Vegetation } \\
\text { types }\end{array}$ & $\begin{array}{l}\text { Soil } \\
\text { layers }\end{array}$ & $\begin{array}{l}\text { Soil } \\
\text { pH }\end{array}$ & SWC/\% & $\begin{array}{l}\text { Sand content } \\
2-0.02 \mathrm{~mm} / \%\end{array}$ & $\begin{array}{l}\text { Silt content } 0.02 \\
\mathrm{~mm}-0.002 \mathrm{~mm} / \%\end{array}$ & $\begin{array}{l}\text { Clay content < } \\
0.002 \mathrm{~mm} / \%\end{array}$ \\
\hline \multirow[t]{4}{*}{$\mathrm{FL}$} & U1 & $\begin{array}{l}7.82 \pm \\
0.10 \\
A b\end{array}$ & $\begin{array}{l}39.61 \pm \\
9.03 \mathrm{Aa}\end{array}$ & $\begin{array}{l}42.58 \pm 11.09 \\
\mathrm{Aa}\end{array}$ & $29.69 \pm 5.52 \mathrm{Aa}$ & $\begin{array}{l}27.73 \pm 5.58 \\
\mathrm{Aa}\end{array}$ \\
\hline & U2 & $\begin{array}{l}7.79 \pm \\
0.09 \\
A b\end{array}$ & $\begin{array}{l}37.34 \pm \\
6.86 \mathrm{Aa}\end{array}$ & $\begin{array}{l}34.13 \pm 10.68 \\
\mathrm{Aa}\end{array}$ & $33.83 \pm 5.26 \mathrm{Aa}$ & $\begin{array}{l}32.04 \pm 5.44 \\
\text { Aa }\end{array}$ \\
\hline & U3 & $\begin{array}{l}7.81 \pm \\
0.14 \\
A b\end{array}$ & $\begin{array}{l}38.12 \pm \\
8.17 \mathrm{Aa}\end{array}$ & $\begin{array}{l}37.30 \pm 10.10 \\
\mathrm{ABa}\end{array}$ & $32.10 \pm 5.14 \mathrm{ABa}$ & $\begin{array}{l}30.60 \pm 5.00 \\
\mathrm{ABa}\end{array}$ \\
\hline & U4 & $\begin{array}{l}7.97 \pm \\
0.05 \\
\mathrm{Aa}\end{array}$ & $\begin{array}{l}33.70 \pm \\
1.26 \\
\mathrm{ABa}\end{array}$ & $\begin{array}{l}41.50 \pm 6.27 \\
\mathrm{Aa}\end{array}$ & $30.30 \pm 3.15 \mathrm{Aa}$ & $\begin{array}{l}28.20 \pm 3.13 \\
\mathrm{Aa}\end{array}$ \\
\hline \multicolumn{7}{|c|}{$\begin{array}{l}\text { Note: GL, grassland; } S L \text {, shrubland; } A L \text {, Abandoned land; FL, forestland; U1, soil (thickness of } 0 \sim 20 \\
\mathrm{~cm} \text { ) in the karst fissures; } U 2 \text {, the soil at a depth of } 40 \mathrm{~cm} \text { in the karst fissures; U3, the soil at a depth of } \\
60 \mathrm{~cm} \text { in the karst near-surface fissures; and U4, the soil at a depth of } 80 \mathrm{~cm} \text { in the karst fissures. The } \\
\text { same below. }\end{array}$} \\
\hline
\end{tabular}

The soil $\mathrm{pH}$ at the same soil depth differs among the different vegetation types, ranged from 7.6 to 7.97 , which was basically weak alkaline.

The water content of fissured soil of the same vegetation type was $\mathrm{U} 1>\mathrm{U} 2>\mathrm{U} 3>\mathrm{U} 4$, and there was no significant difference, which indicated that the upper part of fissured soil can provide more water for plant growth.

In the fissures of the same vegetation type, with the increase of soil depth, the sand content $(0.02-2 \mathrm{~mm})$ decreased, while the silt content $(0.02-0.002 \mathrm{~mm})$ and the clay content $(<0.002 \mathrm{~mm})$ increased (Table 2). However, among the different vegetation types, the sand content $(0.02-2 \mathrm{~mm})$ (including soil depth of U1, U2, U3 and U4) was SL > FL > GL > AL, and the content of silt $(0.02-0.002 \mathrm{~mm})$ and clay (< $0.002 \mathrm{~mm}$ ) were $\mathrm{AL}>\mathrm{GL}>\mathrm{FL}>\mathrm{SL}$.

Changes in SOC, N, P content of the soil in fissures under different vegetation types

i) Changes in the SOC content of fissured soils

The organic carbon content (including soils at depths U1, U2, U3 and U4) was $S L>G L>F L>A L$. Except for $\mathrm{FL}$, soil layer U1 had the highest SOC content in the fissures of the three vegetation types.In U1 soil layer, SL had the highest SOC content (Fig. 2a.). and the SOC contents at depths of U2, U3 and U4 can be ranked as $\mathrm{SL}>\mathrm{GL}>\mathrm{FL}>\mathrm{AL}, \mathrm{GL}>\mathrm{SL}>\mathrm{FL}>\mathrm{AL}, \mathrm{FL}>\mathrm{AL}>\mathrm{SL}>\mathrm{GL}$, respectively. This result shows the high organic carbon content of fissured soils that support the growth of shrubs and grasslands.

ii) Changes in the nitrogen content of fissured soils 
As shown in Fig. 2b., the TN content ranged from $0.65 \mathrm{~g} / \mathrm{kg}$ to $1.13 \mathrm{~g} / \mathrm{kg}$, with little variation and no significant differences in soil layers across vegetation fissures. However, the variation of AN was different from that of TN, where soil layer $\mathrm{U} 1$ had the highest amount of $\mathrm{AN}$ in the same vegetation type (Fig. 2c.). $\mathrm{U} 1$ of SL was not only significantly higher than U2, U3, and U4 but also significantly higher than U1 of the other three vegetation types $(p<0.05)$. SL had the highest AN content of all vegetation types, suggesting that shrubs can increase the AN content of fissured soils.

iii) Variation in phosphorus content of fissured soils

The variation in TP and AP content of fissured soils of different vegetation types was different from the TN and AN content (Fig. 2d., Fig. 2e.). The total phosphorus content of fissure soils, including those at depths of $\mathrm{U} 1, \mathrm{U} 2, \mathrm{U} 3$ and $\mathrm{U} 4$, decreased in the order $\mathrm{AL}>\mathrm{GL}>\mathrm{FL}>\mathrm{SL}$, which suggested that plants in putrefied, grassland had an advantage in accumulating phosphorus in fissured soils. And among the fissures of different vegetation types, FL had the lowest AP content, while SL and AL had higher AP content.Also, the TP and AP contents of four vegetation types U1 were higher than those of U2, U3, and U4, indicating the enrichment characteristics of soil surface TP and fast-acting phosphorus, i.e., surface phosphorus was not efficiently utilized by plants.

iv) Correlation of SOC, N, P content of the soil in fissures

The content of $C, N$, and $P$ in the fissured soil was positively correlated with vegetation type $(P<0.01)$. C and $\mathrm{N}, \mathrm{C}$ and $\mathrm{P}$, and $\mathrm{N}$ and $\mathrm{P}$ content were all linearly correlated and varied similarly (Fig. 3a., 3b., 3c.). The significant correlation coefficients for $\mathrm{C}$ and $\mathrm{N}$ and $\mathrm{C}$ and $\mathrm{P}$ were at the 0.05 level, and the correlation between $\mathrm{N}$ and $\mathrm{P}$ was highly significant $(\mathrm{p}<0.01)$.

Changes in stoichiometric ratios of soil fissures nutrients under different vegetation types

i) $\mathrm{C} / \mathrm{N}$ ratio

The results showed that fissured soils (including $\mathrm{AL}, \mathrm{FL}, \mathrm{SL}$ and $\mathrm{GL}$ soils) $\mathrm{C} / \mathrm{N}$ were ranked $\mathrm{U} 1<\mathrm{U} 2<\mathrm{U} 3<$ $\mathrm{U} 4$, and $\mathrm{C} / \mathrm{N}$ ratio of all fissure soils in the U1, U2, U3and U4 layers ranged from27.44 to $42.48,31.87$ to $37.98,25.6$ to 41.89 , and 21.52 to 42.88 , respectively(Fig. 4a.). C/ $\mathrm{N}$ ratio of fissure soils, including those at depths of $\mathrm{U} 1, \mathrm{U} 2, \mathrm{U} 3$ and $\mathrm{U} 4$, decreased in the order $\mathrm{AL}>\mathrm{GL}>\mathrm{FL}>\mathrm{SL} \rrbracket$ with $\mathrm{AL}$ having the lowest (at all soil levels) $\mathrm{C} / \mathrm{N}$ ratio. The $\mathrm{C} / \mathrm{N}$ for U4 in $\mathrm{FL}$ was 42.88 , which was significantly higher than the fissured soil layer of other vegetation types $(P<0.05)$.

ii) $\mathrm{C} / \mathrm{P}$ ratio

$\mathrm{C} / \mathrm{P}$ ratios for fissure soils (including soils at $\mathrm{U} 1, \mathrm{U} 2, \mathrm{U} 3$ and $\mathrm{U} 4$ depths) are reduced in the order $\mathrm{SL}>\mathrm{FL}>$ $\mathrm{GL}>\mathrm{AL}$ (Fig. 4b.). The $\mathrm{C} / \mathrm{P}$ ratio of fissure soils (including $\mathrm{AL}, \mathrm{FL}, \mathrm{SL}$ and $\mathrm{GL}$ soils) is reduced in the order $\mathrm{U} 2<\mathrm{U} 1<\mathrm{U} 4<\mathrm{U} 3$, and $\mathrm{C} / \mathrm{P}$ ratio of all fissure soils in the $\mathrm{U} 1, \mathrm{U} 2$, U3and $\mathrm{U} 4$ layers ranged from110.21 to $202.24,83.38$ to $219.57,137.61$ to 219.86 , and 133.14 to 183.67 , respectively. Except for the C/P ratio of $\mathrm{AL}$, which increased with soil depth, none of the $\mathrm{C} / \mathrm{P}$ ratios changed significantly for each soil layer under 
the fissures of the three vegetation types. The C/P of U1 and U2 of AL were significantly lower $(\mathrm{P}<0.05)$ than that of the other vegetation types of fissured soil layers.

iii) N/P ratio

The N/P ratios of fissure soils (including AL, FL, SL, and GL soils) decreased by $\mathrm{U} 1<\mathrm{U} 2<\mathrm{U} 3<\mathrm{U} 4$ and were 3.48-5.64, 2.38-6.51, 4.00-6.82, and 3.10-8.02 for U1, U2, U3, and U4, respectively(Fig. 4c.). The N/P for U4 in FL was 3.10, which was significantly lower $(P<0.05)$ than the other vegetation types of fissured soil layers. The N/P ratios of fractured soils (including those at depths U1, U2, U3, and U4) increased in the order of $A L<G L<F L<S L$, with $S L$ and $F L ~ N / P$ ratios higher at $U 2$ and $U 3$, and $G L$ and $A L$ $\mathrm{N} / \mathrm{P}$ ratios highest at $\mathrm{U} 4$ and $\mathrm{U} 1$, respectively.

Environmental factor effects on soil properties

SOC, TN and TP contents were all positively correlated with other soil nutrient contents and most of the chemometric ratios of soil nutrients, moreover, soil SOC contents showed a significant positive correlation with TN and AN contents, indicating that soil nitrogen was mainly present in organic matter as organic nitrogen. Additionally, the nitrogen to phosphorus ratio was highly significantly negatively correlated $(P<$ $0.01)$ with TP and carbon to nitrogen ratio, and highly significantly positively correlated $(P<0.01)$ with carbon to phosphorus ratio(table 3 ).

Table 3. Correlation analysis of soil nutrient content, soil nutrient stoichiometric ratios

\begin{tabular}{|lllllllll|}
\hline Index & C & TP & AP & TN & AN & C/P & C/N & N/P \\
C & 1 & 0.425 & 0.358 & $0.552^{*}$ & $0.679 * *$ & 0.391 & $0.711^{\star *}$ & -0.233 \\
TP & & 1 & 0.088 & -0.029 & 0.184 & $-0.649^{\star *}$ & $0.611^{*}$ & $-0.893^{\star *}$ \\
AP & & & 1 & 0.425 & $0.653^{\star *}$ & 0.225 & -0.173 & 0.256 \\
TN & & & 1 & $0.564^{\star}$ & 0.464 & 0.228 & 0.137 \\
AN & & & & & 1 & 0.408 & 0.178 & 0.053 \\
C/P & & & & & 1 & -0.043 & $0.733^{\star *}$ \\
C/N & & & & & & 1 & $-0.682^{\star *}$ \\
N/P & & & & & & & & 1 \\
\hline
\end{tabular}

*Correlation is significant at $\mathrm{P}<0.05$ level.

** Correlation is significant at $\mathrm{P}<0.01$ level. 
Table 4

Correlation analysis between soil nutrient content and soil physicochemical properties

\begin{tabular}{|llllll|}
\hline Index & PH & SWC & $\begin{array}{l}\text { Sand content 2-0.02 } \\
\mathrm{mm} / \%\end{array}$ & $\begin{array}{l}\text { Silt content } 0.02 \mathrm{~mm}- \\
\mathbf{0 . 0 0 2} \mathrm{mm} / \%\end{array}$ & $\begin{array}{l}\text { Clay content }<0.002 \\
\mathrm{~mm} / \%\end{array}$ \\
\hline C & 0.158 & 0.378 & $0.673^{\star *}$ & $-.674^{\star \star}$ & $-0.669^{\star \star}$ \\
\hline TP & 0.163 & $0.500^{\star}$ & 0.158 & -0.164 & -0.152 \\
\hline AP & -0.144 & 0.25 & 0.491 & -0.473 & $-0.508^{\star}$ \\
\hline TN & 0.329 & -0.091 & $0.802^{\star \star}$ & $-0.813^{\star \star}$ & $-0.787^{\star \star}$ \\
\hline AN & -0.223 & 0.426 & $0.649 \star \star$ & $-0.657^{\star \star}$ & $-0.637^{\star \star}$ \\
\hline
\end{tabular}

Table 5

$\mathrm{SOC}, \mathrm{N}$ and $\mathrm{P}$ contents and their stoichiometric ratios in karst areas and other study areas in China

\begin{tabular}{|lllllll|}
\hline Region & Type & soil layer/ avreage & C/N & C/P & N/P & Reference \\
\hline Global & All soil & avreage & 14.3 & 186 & 13.1 & (Cleveland and Liptzin ,2007) \\
\hline China & All soil & avreage & 11.9 & 61 & 5.2 & (Tian et al.,2010) \\
\hline China & Karst & $0-15 \mathrm{~cm}$ & 13.6 & 92.6 & 6.8 & (Yang et al., 2019) \\
\hline China & Karst & $0-15 \mathrm{~cm}$ & 19.56 & 65.07 & 3.45 & (Wang et al., 2018a) \\
\hline China & Karst & $0-15 \mathrm{~cm}$ & 9.22 & 40.36 & 4.35 & (Wang et al., 2018c) \\
\hline China & GL & avreage & 35.99 & 165.59 & 4.78 & This study \\
\hline China & SL & avreage & 33.58 & 192.15 & 5.96 & This study \\
\hline China & AL & avreage & 28.39 & 148.75 & 4.74 & This study \\
\hline China & FL & avreage & 33.14 & 146.05 & 5.06 & This study \\
\hline
\end{tabular}

\section{Discussions}

Changes in $\mathrm{C}, \mathrm{N}$ and $\mathrm{P}$ in fissured soils

i) Effect of physicochemical properties on nutrients in fissured soils

Soil mechanical composition is a natural property for maintaining soil quality, and a proper proportion of soil mechanical composition facilitates plant root activity and absorption of water and nutrients from the soil. (Su and Zhou et al.,2018).In this study, in the same vegetation type, as the soil layer deepened, the sand content decreased, while the silt content $(0.02-0.002 \mathrm{~mm})$ and clay content increased(Table 4), which is similar to the results of peng et al(2020), and this indicated that the surface soil tends to 
accumulate in cracks and that the underlying soil is buried and continuously compacted; at the rock-soil interface, the water chemistry is very strong and the soil often contains dissolved solids and sand-sized fragments of weathered rock, leading to low clay content here (Peng et al., 2020).

Among the different vegetation types, AL-supporting fissured silt $(0.02-0.002 \mathrm{~mm})$ and clay $(<0.002$ $\mathrm{mm}$ ) had the highest content and the lowest sand content $(0.02-2 \mathrm{~mm})$, as the AL was previously slopecultivated land that was abandoned to grow plants such as dog-tailed grass, and the increase in soil meal and clay particles indicated that the vegetation was effective in amending the soil Mechanical composition, and it is further shown that as the clay content increases, the clay provides a larger surface area as a binding site, allowing the enrichment of organic matter in the fine soil particles and thus an increase in C, N or P. (Ge et al., 2019). Additionally, the fissures supporting SL had the highest sand content $(0.02-2 \mathrm{~mm})$ and the lowest silt $(0.02-0.002 \mathrm{~mm})$ and clay $(<0.002 \mathrm{~mm})$, while the causes of this need to be further investigated. And soil nutrients were positively correlated with Sand content 2-0.02 $\mathrm{mm} / \%$, with a highly significant positive correlation $(\mathrm{p}<0.01)$ for SOC, TN and AN (see table $\mathrm{x}$ ), which is consistent with the findings of yan et al.(2019) (Yan et al., (2019). However, soil nutrients were negatively correlated with silt content $0.02 \mathrm{~mm}-0.002 \mathrm{~mm}$ and clay content $<0.002 \mathrm{~mm}$, it is contrary to the findings of $\mathrm{Ge}$ et al(2019). (Ge et al., 2019) that soil nutrients are mainly concentrated in clays that provide a greater surface area as binding sites, allowing the enrichment of organic matter in fine soil particles. (Ge et al., 2019). Some studies have shown that soil particles enter well-developed karst fissures with rainfallrunoff (Nie et al., 2012). These particles interact with each other; they are filtered, rearranged and eventually piled up (Tang et al., 2016). As a result, karst soils are characterised by a basic 'loose top and tight bottom', where nutrients are concentrated in the sand in the upper part of the fissures, as well as by soil erosion, which can lead to nutrient loss and the loss of farmland on karst slopes. The results of the study suggest that karst near-surface fissures are therefore the main cause of soil nutrient loss (Peng et al., 2017).

Soil water content reflects soil moisture and wetting within the community and can have a direct impact on the exchange of matter and energy between the litter and the soil surface and on the degree of nutrient leaching from the soil.(Kang and Liu et al., 2017). Our result showed that soil water content is mostly positively correlated with nutrients and, within the same vegetation type, the distribution of soil water content gradually decreases from top to bottom, indicating that more of the water required for plant growth comes from the upper part of the fissured soil.

The effect of $\mathrm{pH}$ on soil nutrient characteristics is not significant, probably due to its small spatial heterogeneity in $\mathrm{pH}$ and small differences in soil $\mathrm{pH}$, so that $\mathrm{pH}$ is not a major factor influencing soil $\mathrm{C}, \mathrm{N}$ and $\mathrm{P}$. The effect of $\mathrm{pH}$ on soil $\mathrm{C}, \mathrm{N}$ and $\mathrm{P}$ is not significant, probably due to its small spatial heterogeneity in $\mathrm{pH}$ and small differences in soil $\mathrm{pH}$.

ii) Changes in $\mathrm{C}, \mathrm{N}$ and $\mathrm{P}$ in fissured soils

In this study, the distribution pattern of carbon, nitrogen and phosphorus content in the fissured soils under different vegetation types shows a certain similarity, i.e. the distribution of the upper layer is high 
and the lower layer is low, which is linear. These data showed a general decreasing trend in soil SOC content of different vegetation types with increasing soil depth, which is similar to what many authors have found when studying land-use types associated with karst regions. (Huang and Zhou et al., 2017; Wang and Sheng et al., 2016). In general, apoplastic matter can provide large amounts of organic matter directly to the surface layer, leading to differences in organic matter input between the surface soil and the subsoil (Fröberg et al., 2007),the organic carbon in the surface layer of the fissured soil comes from plant litter and root inputs and is the richest in nutrients (Jackson et al., 1996;Leeand Fitzgerald et al., 2014 ) \as the soil layer deepens, the organic matter content decreases, the quality is poorer and the supply of oxygen may be limited (Bai et al., 2015; Schrumpf et al., 2013) and the degradability of soil organic matter components varies under the action of microbial decomposition, with difficult-to-degrade substances gradually increasing and easy-to-degrade substances gradually decreasing (Wang and Sheng et al.,2016), moreover, the addition of the litter increases the respiration rate of soil micro-organisms, which accelerates the decomposition and release of existing SOCs from the soil(Liao and Long et al.,2016), the main reason for the highest SOC content in SL fissured soils may be the rapid rate of vegetation turnover in scrubland, which allows for the migration of fissured soils downwards of apoplastic material etc. to form nutrient accumulations, similar results were obtained by Chen et al, Fu et al and Chen et al, who reported that shrubland was more effective in increasing SOC during vegetation restoration. (Chen et al., 2007; Chen et al., 2012; Fu et al., 2010) $\square$ and the upward trend in FL in U4 are probably since the plants are rooted in deep fissure soils, where roots and litter replenish the organic matter or the fissure soils have higher water content, lower temperature variability and slower decomposition of the underlying organic matter.

In this study, despite the small annual temperature differences and abundant rainfall in the fissured soils of the karst region, the TN content did not vary much and was not significantly different in all vegetation fissures and in all soil layers. The hydrolysed nitrogen content also decreased with increasing soil depth in the same vegetation type, indicating that nitrogen nutrients are more concentrated in the fissured soil surface layer and are less susceptible to leaching in the fissured soil.

TP and AP are mainly concentrated in the fissured soil surface layer (U1), which is characterised by "surface aggregation". However, because soil phosphating is a sedimentary mineral, the migration rate in the soil is very low (Filippelli, 2008),the vertical variation of TP and AP with the deepening of the soil layer is small, which is consistent with the findings of Peng et al(2016)., Lv et al(2017)., and Li et al(2015). Additionally, the surface layer of the fissured soil contains a high concentration of powders and clay particles, which are strongly adsorbed by soil TP and AP (Hassink et al., 1994; John et al., 2005).

Changes in $\mathrm{C}, \mathrm{N}$ and $\mathrm{P}$ stoichiometry ratios in fissured soils

Soil C/N, C/P and N/P ratios are important parameters for measuring soil quality and organic matter composition and reveal the relative availability of soil nutrients (Wang et al.,2008), the changes in $\mathrm{C} / \mathrm{N}$ and N/P of fissured soils (including AL, FL, SL and GL soils) under different vegetation types in our study were $\mathrm{U} 1<\mathrm{U} 2<\mathrm{U} 3<\mathrm{U} 4$ and $\mathrm{C} / \mathrm{P}: \mathrm{U} 2<\mathrm{U} 1<\mathrm{U} 4<\mathrm{U} 3$. In contrast to Qiao et al.'s findings (Qiao et al., 2020), 
$\mathrm{C} / \mathrm{N}$ and N/P decrease progressively as the soil layer deepens, probably due to the different spatial distribution of roots in deep karstic fissures and hence the different utilisation of soil $\mathrm{N}$ elements. In the 60-80 cm fissured soils of SL and FL, a large number of plant roots are distributed and take up a large amount of $\mathrm{N}$ from the soil, thus making soil $\mathrm{C} / \mathrm{N}$ and $\mathrm{N} / \mathrm{P}$ larger than the surface layer.

Additionally, the amount of nitrogen affects the spatial heterogeneity of soil carbon, nitrogen and phosphorus ratios by influencing the physical and chemical properties of the soil, nutrient levels (e.g. C, N, $\mathrm{P})$ and microbial activity. As can be seen from (Figure $\mathrm{xx}$ ), the lower the nitrogen amount, the higher the soil $\mathrm{C} / \mathrm{N}$ and the lower the N/P; the higher the nitrogen amount, the lower the soil $\mathrm{C} / \mathrm{N}$ and the higher the N/P.

Overall, $\mathrm{C} / \mathrm{N}, \mathrm{C} / \mathrm{P}$ and N/P are $\mathrm{AL}<\mathrm{FL}<\mathrm{SL}<\mathrm{GL}, \mathrm{AL}<\mathrm{GL}<\mathrm{FL}<\mathrm{SL}$ and $\mathrm{AL}<\mathrm{GL}<\mathrm{FL}<\mathrm{SL}$, respectively. $\mathrm{C} / \mathrm{P}$, $\mathrm{C} / \mathrm{N}$ and N/P for $\mathrm{AL}$ are minimum and $\mathrm{C} / \mathrm{P}$ and N/P for $\mathrm{SL}$ are maximum. Compared to other types of fractured soils, most of the nutrients in these soils have been absorbed by crops, affecting their $\mathrm{C}, \mathrm{N}$ and $\mathrm{P}$ storage content, so soil C/N, C/P and N/P are lower in AL than in other land-use types. The herbaceous succession under SL, the apoplastic and root succession of the regenerating stands and the biological fixation result in a large input of $C$ and N (Gundale et al., 2011; Johnson and Curtis, 2001; Yuan and Chen, 2010), the nutrient accumulation is high, so C/P, N/P is maximum. Zhou et al.(Zhou et al., 2018) also found that the spatial pattern of soil carbon to nitrogen ratios across the profile was not strongly related to vegetation cover. And $\mathrm{C}$ and $\mathrm{N}$ are structural components whose accumulation and consumption are relatively constant (Cleveland and Liptzin et al.,2007).

Our results show that the mean soil C: N, C: $\mathrm{P}$ and N: P ratios in the study area range from 28.39 to 35.99 , 146.05 to 192.15 and 4.74 to 5.76 , respectively, and that it has been found that the karst region has the highest $\mathrm{C}: \mathrm{N}(9.22-19.56), \mathrm{C}: \mathrm{P}(40.36-92.6)$ and $\mathrm{N}: \mathrm{P}(3.45-98)$ ratios in the study area. (6.80), both higher than China's C: N (11.9) and C: P (61.0) and global C: N (14.3) and C: P (186.0), and lower than China's N: P (5.2) and global N: P (13.1). High C: N, C:P in the study area means a slow mineralisation rate of these nutrients (Cleveland and Liptzin et al.,2007),Furthermore, the significant correlation between soil SOC content and the carbon to nitrogen, carbon to phosphorus ratio (Table 5) also confirms that changes in soil SOC content in the study area are highly constrained by changes in soil SOC content. Soil N: P is significantly higher than in the other areas, suggesting that there may be a relative deficit of soil $P$ in the study area or a relative surplus of soil N (Wang and Wang et al.,2018).

\section{Conclusions}

The physicochemical properties, nutrient and stoichiometric characteristics of karstic rift soils were evaluated and the results showed that soil $\mathrm{pH}$ at the same soil depth varies with the type of vegetation and is basically weakly alkaline. The water content of the soil also decreases as the depth of the soil increases, and the soil in the upper part of the fissure gives more water for plant growth. Under the same vegetation type, the silt content $(0.02-0.002 \mathrm{~mm})$ and clay content $(<0.002 \mathrm{~mm})$ increased and the sand content $(0.02-2 \mathrm{~mm})$ decreased with increasing soil depth, with $\mathrm{AL}$ and $\mathrm{GL}$ showing better soil structure. 
There was little change in TN content from the surface layer of the fissure to the lower layer, and a general decrease in AN, TP and AP content in the fissure. In general, SOC, nitrogen and phosphorus were mainly concentrated in the surface soil compared to the other soil layers of the fissure. SL has the highest SOC, AN and AP content, especially in soil layer U1, which shows high fertility, but low TP content. The $\mathrm{C} / \mathrm{N}, \mathrm{N} / \mathrm{P}$ and $\mathrm{C} / \mathrm{P}$ ratios of fissured soils overall decrease with increasing soil depth. SL has higher $\mathrm{C} / \mathrm{P}$ and N/P and lowers $\mathrm{C} / \mathrm{N}$, while the opposite is true for $\mathrm{AL}$. The higher $\mathrm{C} / \mathrm{N}, \mathrm{C} / \mathrm{P}$ and N/P variations indicate that the karstic rift soils are severely deficient in $\mathrm{N}$ and $\mathrm{P}$ and therefore some fertiliser, such as $\mathrm{N}$ and $\mathrm{P}$, can be applied. Rift soils are one of the key conditions for the implementation of vegetation restoration in karstic stone desertification areas. The low nutrient content and high ecological stoichiometry of karstic rift soils indicate that rift soils in karstic areas need more soil nutrient management, improvement of quality conditions. Therefore, based on our results, it is recommended that priority be given to the selection of herbaceous plants to improve the structure of fissured soils and enhance soil nutrients.

\section{Declarations}

\section{Acknowledgements}

This work was funded by the National Key Research and Development Program (2016YFC0502604), Guizhou First-class Discipline Construction Project (GNYL [2017]007) and the National Natural Science Foundation of China $(41671275,41461057)$. In addition, we appreciate the project support provided by the Funded by China Postdoctoral Science Foundation(2020M673296).

\section{References}

Andrews SS, Karlen DL, Cambardella CA(2004) The soil management assessment framework: a quantitative soil quality evaluation method. Soil Science Society of America Journal, 68(6): 1945-1962. doi: 10.2136/sssaj2004.1945.

Bai R, Xi D, He J-Z, Hu H-W, Fang Y-T, Zhang L-M (2015) Activity, abundance and community structure of anammox bacteria along depth profiles in three different paddy soils. Soil Biology and Biochemistry 91:212-221. doi:10.1016/j.soilbio.2015.08.040.

Bai X, Wang S, Xiong K (2013) Assessing spatial-temporal evolution processes of karst rocky desertification land: indications for restoration strategies. Land Degrad. Dev. 24 (1), 47-56.

Chen H, Zhang W, Wang K, Hou Y (2012) Soil organic carbon and total nitrogen as affected by land use types in karst and non-karst areas of northwest Guangxi, China. Journal of the Science of Food and Agriculture 92:1086-1093. doi:10.1002/jsfa.4591.

Chen L, Gong J, Fu B, Huang Z, Huang Y, Gui L (2007) Effect of land use conversion on soil organic carbon sequestration in the loess hilly area, loess plateau of China. Ecological Research 22:641-648. 
doi:10.1007/s11284-006-0065-1.

Cleveland C C., Liptzin D (2007) C:N:P stoichiometry in soil: is there a "Redfield ratio" for the microbial biomass?, Vol 85 . Biogeochemistry 85:235-252.

Febles-González JM, Vega-Carreño MB, Amaral-Sobrinho NMB, Tolón-Becerra A, Lastra-Bravo XB (2014) SOIL LOSS FROM EROSION IN THE NEXT 50 YEARS IN KARST REGIONS OF MAYABEQUE PROVINCE, CUBA. Land Degradation \& Development 25:573-580. doi:10.1002/ldr.2184.

Filippelli, GM (2008) The Global Phosphorus Cycle: Past, Present, and Future. Elements 4 (2), 89-95.

Ford D, Williams PW (2007) Karst hydrogeology and geomorphology. John Wiley, Chichester.

Fröberg M, Jardine PM, Hanson PJ, Swanston CW, Todd DE, Tarver JR, Garten CT (2007) Low Dissolved Organic Carbon Input from Fresh Litter to Deep Mineral Soils. Soil Science Society of America Journal 71:347-354. doi:10.2136/sssaj2006.0188.

Fu X, Shao M, Wei X, Horton R (2010) Soil organic carbon and total nitrogen as affected by vegetation types in Northern Loess Plateau of China. Geoderma 155:31-35. doi:10.1016/j.geoderma.2009.11.020.

Ge N, Wei X, Wang X, Liu X, Shao M, Jia X, Li X, Zhang Q(2019) Soil texture determines the distribution of aggregate-associated carbon, nitrogen and phosphorous under two contrasting land use types in the Loess Plateau. Catena 172, 148-157.

Gundale MJ, Deluca TH, Nordin A (2011) Bryophytes attenuate anthropogenic nitrogen inputs in boreal forests. Global Change Biology 17:2743-2753. doi:10.1111/j.1365-2486.2011.02407.x.

Han G, Li F, Tang Y (2015)Variations in soil organic carbon contents and isotopic compositions under different land uses in a typical karst area in Southwest China. Geochemical Journal 49:63-71. doi:10.2343/geochemj.2.0331.

Hassink J, Neutel AM, ruiter PC (1994) C and N mineralization in sandy and loamy grassland soils: The role of microbes and microfauna. Soil Biology \& Biochemistry 26 (11), 1565-1571.

Chai H, Yu G, He N, Wen D, Li J, Fang J (2015) Vertical distribution of soil carbon, nitrogen, and phosphorus in typical chinese terrestrial ecosystems. Chinese Geographical Science, 25(5), 549-560.

Jackson RB, Canadell J, Ehleringer JR, Mooney HA, Sala OE, Schulze ED(1996) A global analysis of root distributions for terrestrial biomes. Oecologia 108 (3), 389-411.

John B, Yamashita T, Ludwig B, Flessa H (2005) Storage of organic carbon in aggregate and density fractions of silty soils under different types of land use. Geoderma 128:63-79.

doi:10.1016/j.geoderma.2004.12.013. 
Johnson DW, Curtis PS (2001) Effects of forest management on soil C and N storage: meta analysis. Forest Ecology and Management 140:227-238. doi:10.1016/S0378-1127(00)00282-6.

Kang B, Liu S, Cai D, Lu L, He R, Gao Y, Di W (2010) Soil physical and chemical characteristics under different vegetation restoration patterns in China south subtropical area. Chinese Journal of Applied Ecology. 21(10):2479-2486. (in Chinese)

Lal R (2004) Soil carbon sequestration impacts on global climate change and food security. Science, 304(5677): 1623-1627. doi: 10.1126/science.1097396.

Long J, Liao H, Li J, Chen C (2012) Relationships Between Soil and Rocky Desertification in Typical Karst Mountain Area Based on Redundancy Analysis. Environmental Science. 33(06):2131-2138. (in Chinese)

Li D, Wen L, Yang L, Luo P, Xiao K, Chen H, Zhang W, He X, Chen H, Wang K (2017a) Dynamics of soil organic carbon and nitrogen following agricultural abandonment in a karst region. Journal of Geophysical Research-Biogeosciences 122:230-242. doi:10.1002/2016JG003683.

Li Z, Xu X, Liu M, Li X, Zhang R, Wang K, Xu C (2017b) State-space prediction of spring discharge in a karst catchment in southwest China. Journal of Hydrology 549:264-276. doi:10.1016/j.jhydrol.2017.04.001.

Li W, Zheng Z, Li T (2015) Ecological stoichiometry of soil carbon,nitrogen and phosphorus within soil aggregates in tea plantations with different ages. Chinese Journal of Applied Ecology. 26(01):9-16. (in Chinese)

Liao H, Long J (2011) Variation of soil organic carbon under different vegetation types in Karst mountain areas of Guizhou Province, Southwest China. Chinese Journal of Applied Ecology. 22(09):2253-2258. (in Chinese)

Lv J, Yan M, Song Z, Guan J, Shi W, Du, S (2017) Ecological stoichiometry characteristics of soil carbon, nitrogen, and phosphorus in an oak forest and a black locust plantation in the Loess hilly region.Acta Ecologica Sinica. 37(10):3385-3393. (in Chinese)

Ma T, Deng X, Chen L, Xiang W (2020) The soil properties and their effects on plant diversity in different degrees of rocky desertification. Science of the Total Environment 736.

Nie Y, Chen H, Wang K., Yang J (2012) Water source utilization by woody plants growing on dolomite outcrops and nearby soils during dry seasons in karst region of Southwest China. Journal of Hydrology 420, 264-274.

Peng J, Lin C, Hong H, Lin W, Xiong D, Yang Z, Yang Y (2016) Effect of forest regeneration on soil phosphorus in mid-subtropical area. Acta Ecologica Sinica. 36(24):8015-8024. (in Chinese) 
Peng X, Dai Q, Ding G, Shi D, Li C (2020) Impact of vegetation restoration on soil properties in nearsurface fissures located in karst rocky desertification regions. Soil and Tillage Research 200:104620. doi:10.1016/j.still.2020.104620.

Peng X, Dai Q, Ding G, Zhu C, Li C (2017) Distribution and accumulation of trace elements in rhizosphere and non-rhizosphere soils on a karst plateau after vegetation restoration. Plant and Soil 420 (1-2), 49-60.

Peng T, Wang S (2012) Effects of land use, land cover and rainfall regimes on the surface runoff and soil loss on karst slopes in southwest China. Catena 90 (1), 53-62.

Qiao Y, Wang J, Liu H, Huang K, Yang Q, Lu R, Yan L, Wang X, Xia J (2020) Depth-dependent soil C-N-P stoichiometry in a mature subtropical broadleaf forest. Geoderma 370.

doi:10.1016/j.geoderma.2020.114357.

Ruttenberg K C(2003) The Global Phosphorus Cycle. Treatise on Geochemistry, 8:585-643.

Schrumpf M, Kaiser K, Guggenberger G, Persson T, Koegel-Knabner I, Schulze E-D (2013) Storage and stability of organic carbon in soils as related to depth, occlusion within aggregates, and attachment to minerals. Biogeosciences 10:1675-1691. doi:10.5194/bg-10-1675-2013.

Smith P, Ashmore MR, Black HIJ, Burgess PJ, Evans CD, Quine TA, Thomson AM, Hicks K, Orr HG (2013) REVIEW: The role of ecosystems and their management in regulating climate, and soil, water and air quality. J Appl Ecol 50 (4), 812-829.

Tang Y, Sun K, Zhang X, Zhou J, Yang Q, Liu Q (2016) Microstructure changes of red clay during its loss and leakage in the karst rocky desertification area. Environmental Earth Sciences 75. doi:10.1007/s12665-016-5419-6.

Tian H, Chen G, Zhang C, Melillo JM, Hall CAS (2010) Pattern and variation of C:N:P ratios in China's soils: a synthesis of observational data. Biogeochemistry 98, 139-151. doi:10.1007/s10533-009-9382-0, $13 \mathrm{pp}$.

Vitousek PM (2004) Nutrient Cycling and Limitation: Hawai'i as a Model System. Princeton: Princeton University Press.

Wang L, Wang P, Sheng M, Tian J (2018a) Ecological stoichiometry and environmental influencing factors of soil nutrients in the karst rocky desertification ecosystem, southwest China. Global Ecology and Conservation 16. doi:10.1016/j.gecco.2018.e00449.

Wang L, Sheng M, Li R (2016) Response of soil organic carbon to rocky desertification succession in south China karst and the analysis of its influence factors. Ecological Science. 35(01):47-55. (in Chinese)

Wang L, Wang P, Sheng M, Tian J (2018) Ecological stoichiometry and environmental influencing factors of soil nutrients in the karst rocky desertification ecosystem, southwest China. In Global Ecology and 
Wang M, Chen H, Zhang W, Wang K (2018c) Soil nutrients and stoichiometric ratios as affected by land use and lithology at county scale in a karst area, southwest China. Science of the Total Environment 619:1299-1307. doi:10.1016/j.scitotenv.2017.11.175.

Wang M, Chen H, Zhang W, Wang K (2020) Soil organic carbon stock and its changes in a typical karst area from 1983 to 2015. Journal of Soils and Sediments. doi:10.1007/s11368-020-02745-6.

Wang S-J, Liu Q-M, Zhang D-F (2004) Karst rocky desertification in southwestern China: geomorphology, landuse, impact and rehabilitation. Land Degradation \& Development 15:115-121. doi:10.1002/ldr.592.

Wang, S (2008) Ecological stoichiometry characteristics of ecosystem carbon, nitrogen and phosphorus elements. Acta Ecol. Sin. 8, 3937-3947. https://doi.org/10.3321/j. issn:1000-0933.2008.08.054.

Waltham T (2008) Fengcong, fenglin, cone karst and tower karst. Cave Karst Sci. Cave \& Karst Science, 35(3):77-88.

Wen L, Li D, Yang L, Luo P, Chen H, Xiao K, Song T, Zhang W, He X, Chen H, Wang K (2016) Rapid recuperation of soil nitrogen following agricultural abandonment in a karst area, southwest China. Biogeochemistry 129:341-354. doi:10.1007/s10533-016-0235-3.

Xiong K, Yin C, Ji H (2018) Soil erosion and chemical weathering in a region with typical karst topography. Environmental Earth Sciences, 77(13):500.

Yan Y, Dai Q, Wang X, Jin L, Mei L (2019) Response of shallow karst fissure soil quality to secondary succession in a degraded karst area of southwestern China. Geoderma 348:76-85. doi:10.1016/j.geoderma.2019.04.017.

Yang H, Zhang P, Zhu T, Li Q, Cao J (2019) The Characteristics of Soil C, N, and P Stoichiometric Ratios as Affected by Geological Background in a Karst Graben Area, Southwest China. Forests 10. doi:10.3390/f10070601.

Yuan ZY, Chen HYH (2010) Fine Root Biomass, Production, Turnover Rates, and Nutrient Contents in Boreal Forest Ecosystems in Relation to Species, Climate, Fertility, and Stand Age: Literature Review and Meta-Analyses. Critical Reviews in Plant Sciences 29:204-221. doi:10.1080/07352689.2010.483579.

Zhou Y, Boutton TW, Wu XB (2018) Soil C:N:P stoichiometry responds to vegetation change from grassland to woodland. Biogeochemistry 140:341-357. doi:10.1007/s10533-018-0495-1.

\section{Figures}




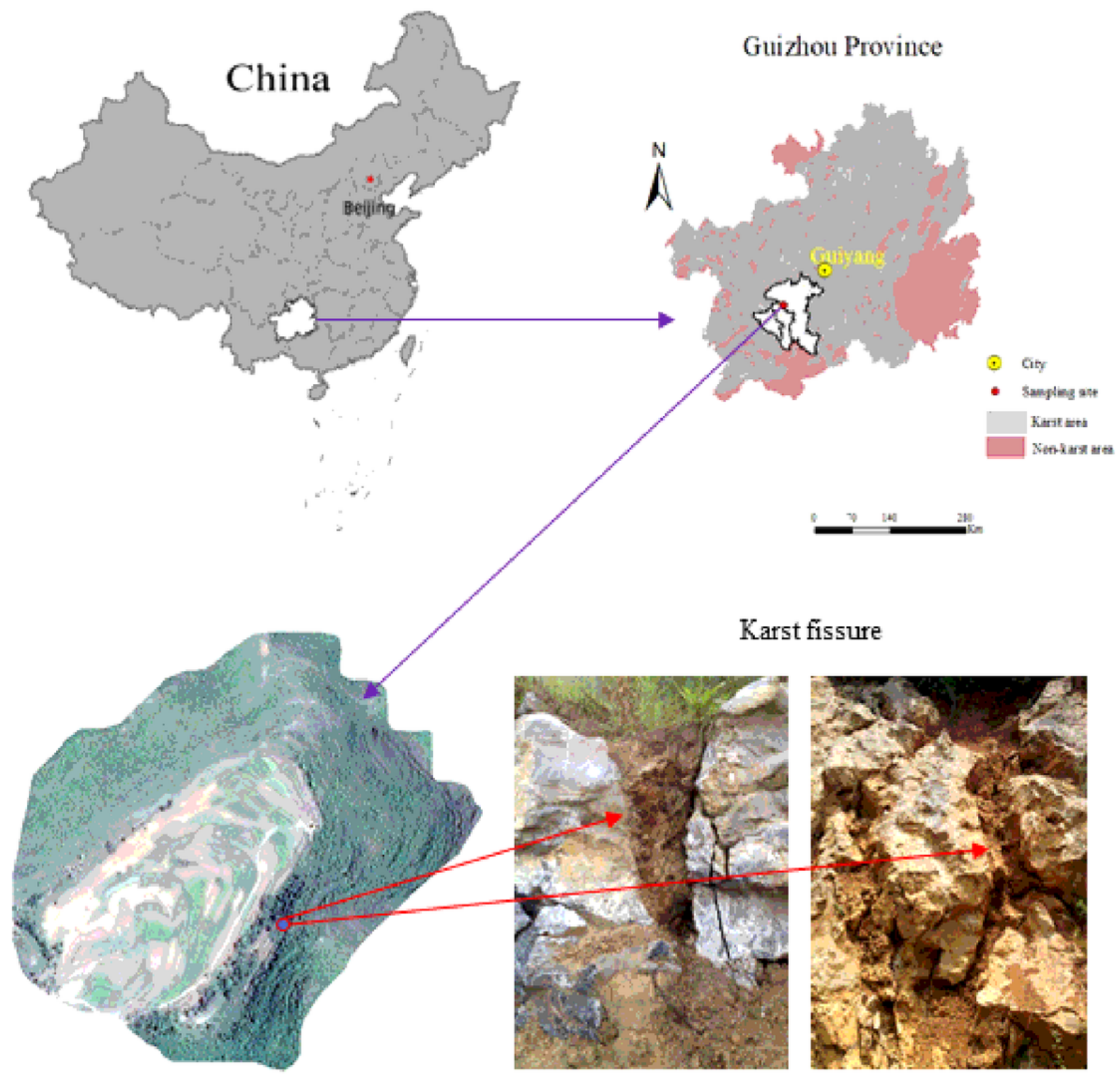

\section{Shuanglongshan ·Anshun City Guizhou Province - China}

\section{Figure 1}

Geological map of the study area and sampling area Note: The designations employed and the presentation of the material on this map do not imply the expression of any opinion whatsoever on the part of Research Square concerning the legal status of any country, territory, city or area or of its authorities, or concerning the delimitation of its frontiers or boundaries. This map has been provided by the authors. 

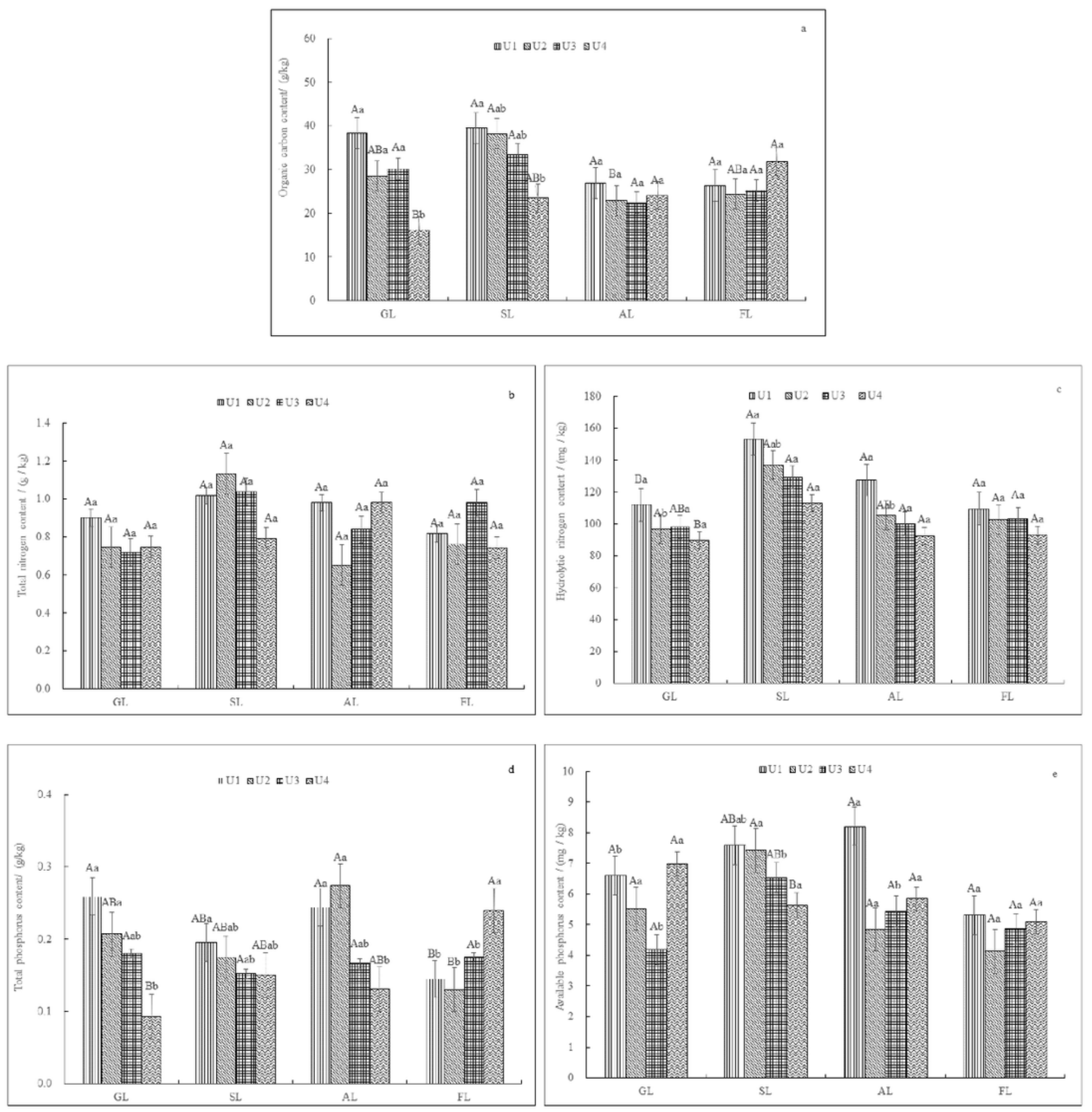

Figure 2

Soil nutrient content of fissures of different vegetation types 

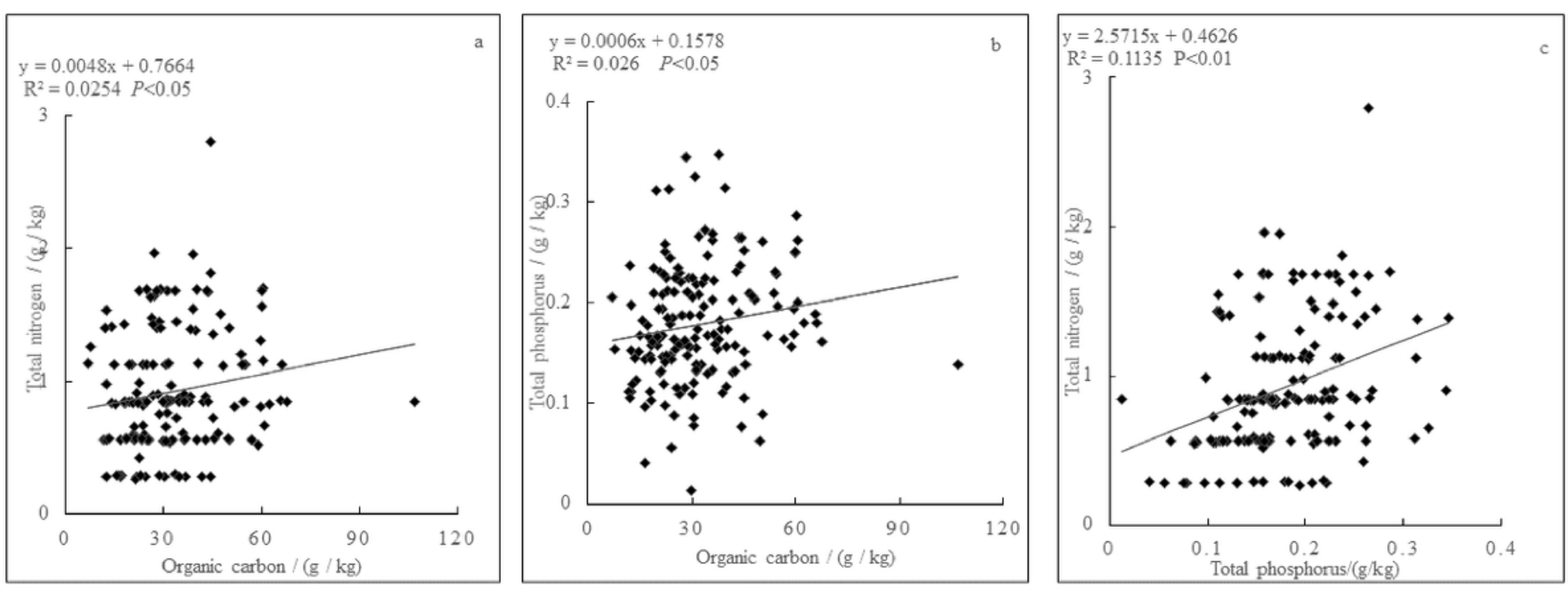

Figure 3

Correlation study of organic carbon, total nitrogen and total phosphorus in soils 

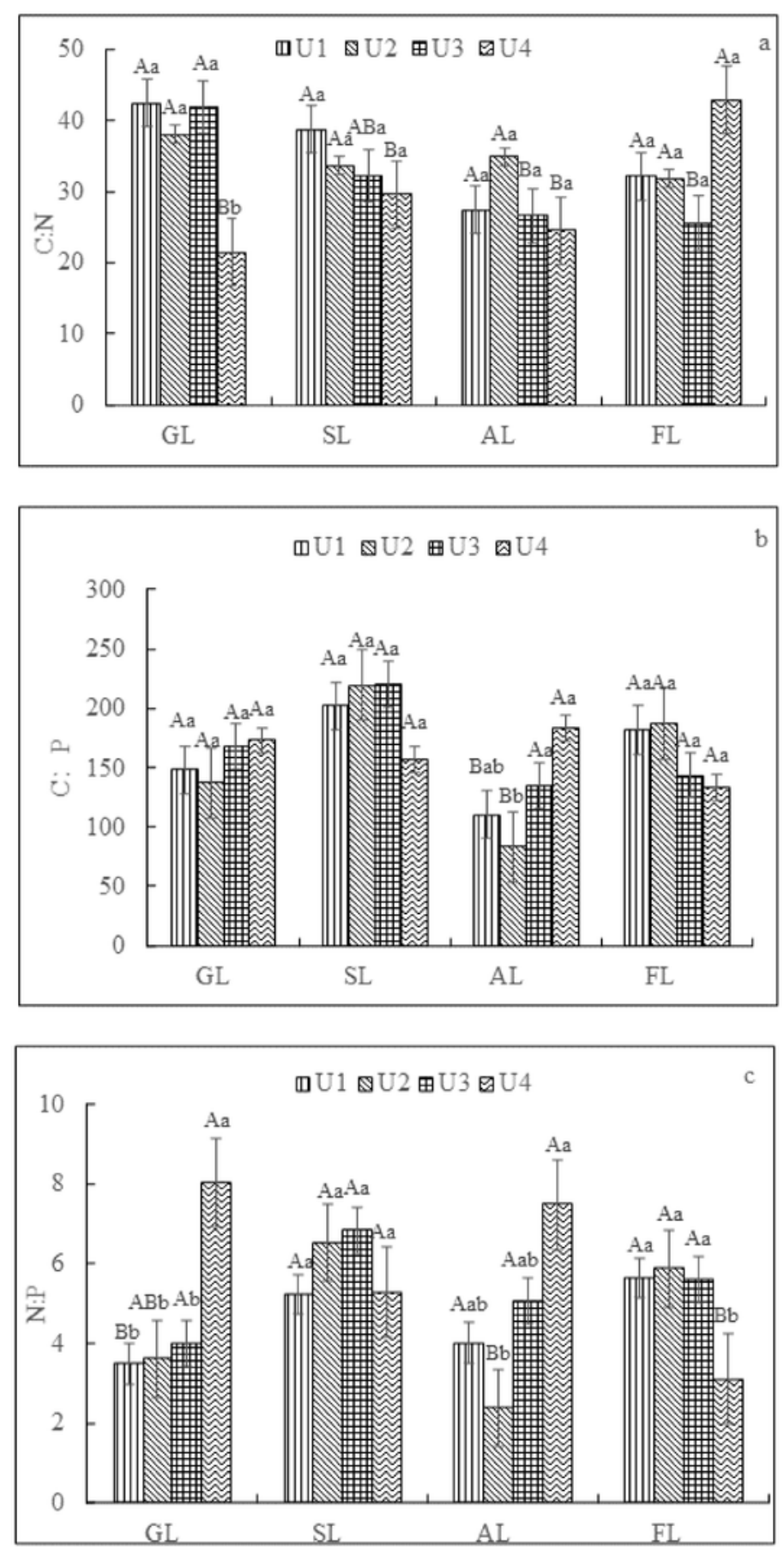

Figure 4

Soil stoichiometry characteristics of C: N, C:P and N:P for different vegetation types 